\title{
Suitability of Suluu-Terek Basalt Deposits for Stone Casting
}

\author{
Zhanbolot Aidaraliev', Imiyla Rysbaeva², Rakhat Atyrova ${ }^{3}$, Akimbek Abdykalykov', \\ Baktygul Bekbolot Kyzy ${ }^{3}$, Chynara Zholdoshova3 ${ }^{3}$, Nematilla Sopubekov ${ }^{4}$, Altynbek Kuduev5, \\ Iurii Dubinin ${ }^{1}$, Zhypargul Abdullaeva ${ }^{*}$ (i)
}

${ }^{1}$ Department of Physics and Applied Chemistry, Kyrgyz State University of Building, Transport and Architecture Named after N. Isanov, Bishkek, Kyrgyzstan

${ }^{2}$ Department of Light Industry Product Technology, Kyrgyz State Technical University Named after I. Razzakov, Bishkek,

Kyrgyzstan

${ }^{3}$ Department of Automated Systems and Digital Technologies, Osh State University, Osh, Kyrgyzstan

${ }^{4}$ Department of Institute of Chemistry and Biotechnology, Kyrgyz Republic National Academy of Sciences, Bishkek, Kyrgyzstan

${ }^{5}$ Department of Networks and Telecommunication Systems, Osh Technological University, Osh, Kyrgyzstan

${ }^{6}$ Science and Research Department, Osh State University, Osh, Kyrgyzstan

Email: *jypar.science@oshsu.kg

How to cite this paper: Aidaraliev, Z., Rysbaeva, I., Atyrova, R., Abdykalykov, A., kyzy, B.B., Zholdoshova, C., Sopubekov, N., Kuduev, A., Dubinin, I. and Abdullaeva, Z. (2022) Suitability of Suluu-Terek Basalt Deposits for Stone Casting. Journal of Minerals and Materials Characterization and Engineering, 10, 1-14.

https://doi.org/10.4236/jmmce.2022.101001

Received: November 2, 2021

Accepted: December 10, 2021

Published: December 13, 2021

Copyright $\odot 2022$ by author(s) and Scientific Research Publishing Inc. This work is licensed under the Creative Commons Attribution International License (CC BY 4.0).

http://creativecommons.org/licenses/by/4.0/

\begin{abstract}
This article is presenting history of stone casting and analysis of basalt raw materials assessment from other countries for stone casting technology and various basalts compositions were considered. Analytical methods for calculating composition of charge require a long calculation time and plotting diagrams, each method has its own advantages and disadvantages. As a research significance, we have proposed an experimental calculation method for calculating raw materials after charging. Analysis of the composition, structure of basalts and charging materials were used in the stone casting technology. According to the comparison method, the required amount of charging materials was calculated for the Suluu-Terek 1, Suluu-Terek 2 and Berestovetsk deposits. The calculated data was confirmed by experimental melts in the process of stone casting.
\end{abstract}

\section{Keywords}

Petrology, Basalt-Stone Casting, Suitability of Raw Materials, Aluminosilicate Crystalline Alloy, Charging, Raw Material Comparison Method

\section{Introduction}

Based on petrology it is possible to carry out computational and experimental works, simulate the melting and crystallization processes of melts and study min- 
eral formation in fused systems [1]. Basalts are used as raw materials, in production of basalt fiber, stone products (paving stones, pipes, gutters, etc.) and petrositalls [2]. Basalt-stone casting is used as an alternative to ferrous and non-ferrous metals, metal alloys and other materials for protection against wear, corrosion of equipment, as well as in protection against radiation [3].

Stone casting consists of a crystalline phase $(5 \div 800$ microns $)$ and an amorphous glass phase. Experiments on melting of basalts aimed to obtain glass-crystalline materials and to determine possibilities of their application in industry were held in Paris at the beginning of 20th century. The results obtained were used in creation of stone foundries in France and then in Germany in 1920s.

The S.J. Goll in 1801 was the first who defined conditions for obtaining cast stone products from basalt melts, and the Englishman T. Watt in 1804 established heat treatment in stone casting from basalt, and his compatriot Adcock in 1854 filed a patent for obtaining cast products from stone casting. The practical use of cast products started in 1830 when several streets in Chicago were decorated with cast products from the slag of a metallurgical plant. In 1921-1922, factories with a capacity of 10 - 12 thousand tons per year from local raw materials without charging began to operate in France and Germany. In the town named Strachowice, a plant has been operating on local raw materials without charging in Poland since 1954; the shaft-bath furnace produces 2.6 tons of stone casting per day. Plants in Linz on the Rhine, in Czech Republic in Stara Voda, producing 8.5 thousand tons of castings per year, operate without charging on local raw materials. In Vitry, France, there is a foundry with a capacity of about 10 tons per day.

In Russia, experimental research on the melting of basalts began in the 1920s of the last century under the leadership of F. Levinson-Lessing, A. Ginsberg and P. Florensky. Academician Levinson Lessing F.Y. in 1926 established the stone foundry production in the USSR. Since those times, numerous factories began to build, the Yerevan stone foundry in 1933, in 1943 in the Norilsk mining and processing plant, a stone casting workshop was launched. In 1954, the Pervouralsky stone foundry, Donetsk plant, Krivoy Rog, Balkhash, Karelia, Magnitogorsk, etc. Various basalts, diabase, andesite-basalts, copper slags, metallurgical slags, oil shale ash and others can serve as raw materials for stone casting. Basalt deposits that do not require charging of a unit are deposits located in Czechoslovakia, Germany, France, Poland, the rest require charging.

The most intensively stone foundry production and the corresponding research work developed in the 50-60s of the last century in connection with the problems solution to increase the durability of equipment in conditions of abrasive wear and aggressive media. Petrographers G. Rashin, V. Lapin, S. Chetverikov, A. Tsvetkov and others made a great contribution to scientific petrology foundations development [3]-[12].

Among the rocks of magmatic and sedimentary origin [13], a large number of 
deposits have been studied by practically all the republics of the former Soviet Union. Gabro pyrites of East Kazakhstan, tephrite-basalts of the Chimken region, the Far East, the Urals, the North Caucasus, Ukraine, Karelia and many others. In this respect, basalts in Kyrgyzstan were investigated insufficiently.

\section{Research Methods of Basalt Raw Materials for Stone Casting}

To assess the suitability of producing stone casting, the chemical and mineralogical compositions of raw materials first examined. The suitability of raw materials for stone casting determined by various methods [11] [12] [14].

B.F Ormont proposed an asymmetric diagram, but it does not allow taking into account the effect of iron oxides on the crystallization process. Considering that processes taking place during the charge melting are very complex, therefore, constructed asymmetric diagram does not always give a positive result [13].

P. Niggli proposed the following scheme: based on the oxides content, "basic molecules", the coefficients $\mathrm{L}, \mathrm{M}$, and $\mathrm{Q}$ and "small components" $\mathrm{P}, \mathrm{S}, \mathrm{Cl}, \mathrm{F}$, etc. were considered in formation of main rock-forming minerals [14] [15]. Groupings are the basis for construction of pyroxenes, olivines, plagioclases, reflecting the ratio of crystalline and glassy phases. The method is laborious and it is advisable to use special computer programs for calculation.

A.G. Kotlova proposed another assessment method, which based on a number of well-known provisions:

1) Stone products of monomineral composition have higher technical properties in comparison with polymineral;

2) Preference should be given to pyroxene casting (the crystal structure of silicates in which the $\mathrm{SiO}_{4}$ tetrahedral are interconnected in endless chains);

3) In petrochemical calculations, it is necessary to use molecular amounts of a substance (MA):

$$
\text { MA\% = Oxide content } / \text { Molecular mass }
$$

4) Pyroxene casting should create by saturation of silicon oxide $\mathrm{SiO}_{2}$ with alkali, hemi oxides and basic oxides;

5) Pyroxenes are capable of producing continuous rows for the entire pyroxene group and makes it possible to obtain monomineral castings. All pyroxene species can combine to form monoclinic pyroxene.

According to the method of Kotlova A.G. the percentage of this oxide is divided by the molecular weight, then silicon oxide is saturated with alkali metals based on the process of obtaining jadeite $\mathrm{NaAlSi}_{2} \mathrm{O}_{6}$, followed by saturation with hemi oxides to obtain three Chermak molecules $\left(\mathrm{CaO} \mathrm{Al} \mathrm{O}_{3} \mathrm{SiO}_{2}\right)\left(\mathrm{CaO} \mathrm{Fe}_{2} \mathrm{O}_{3}\right.$ $\left.\mathrm{SiO}_{2}\right)\left(\mathrm{CaO} \mathrm{Al}_{2} \mathrm{O}_{3} \mathrm{TiO}_{2}\right)$. After saturation of sesquioxides, part of $\mathrm{CaO}$ goes to the formation of $\mathrm{CaO}+\mathrm{SiO}_{2}$, and finally, due to the interaction of $\mathrm{MgO}$ and $\mathrm{FeO}$, metasilicates were formed. As a result, a $\mathrm{SiO}_{2}$ residue remains in acidic rocks, which must be saturated with the basic oxides $\mathrm{CaO}, \mathrm{MgO}, \mathrm{FeO}$. The lack of $\mathrm{SiO}_{2}$ is replenished with acidic oxides, most often with quartz sand. 
Vector diagram by Zavaritsky A.N. is represented in Figure 1. Ginsberg A.S. proposed raw materials assessment based on a projection diagram, shown in Figure 2. The tops in the diagram reflect oxides total value $\mathrm{A}\left(\mathrm{SiO}_{2}+\mathrm{Al}_{2} \mathrm{O}_{3}+\right.$ $\left.\mathrm{TiO}_{2}\right) \cdot \mathrm{B}\left(\mathrm{Fe}_{2} \mathrm{O}_{3}+\mathrm{FeO}+\mathrm{CaO}+\mathrm{MgO}+\mathrm{MnO}\right), \mathrm{C}\left(\mathrm{K}_{2} \mathrm{O}+\mathrm{Na}_{2} \mathrm{O}\right)$. Zone 6-7 gives an acceptable composition, but this diagram in Figure 1 cannot be applied to some synthetic castings.

Subsequently, he proposed a simpler method for assessing the modulus of acidity:

$$
\mathrm{K}=\left(\mathrm{SiO}_{2}+\mathrm{Al}_{2} \mathrm{O}_{3}+\mathrm{TiO}_{2}\right) /\left(\mathrm{CaO}+\mathrm{MgO}+\mathrm{FeO}+\mathrm{Fe}_{2} \mathrm{O}_{3}+\mathrm{Na}_{2} \mathrm{O}+\mathrm{K}_{2} \mathrm{O}\right)
$$

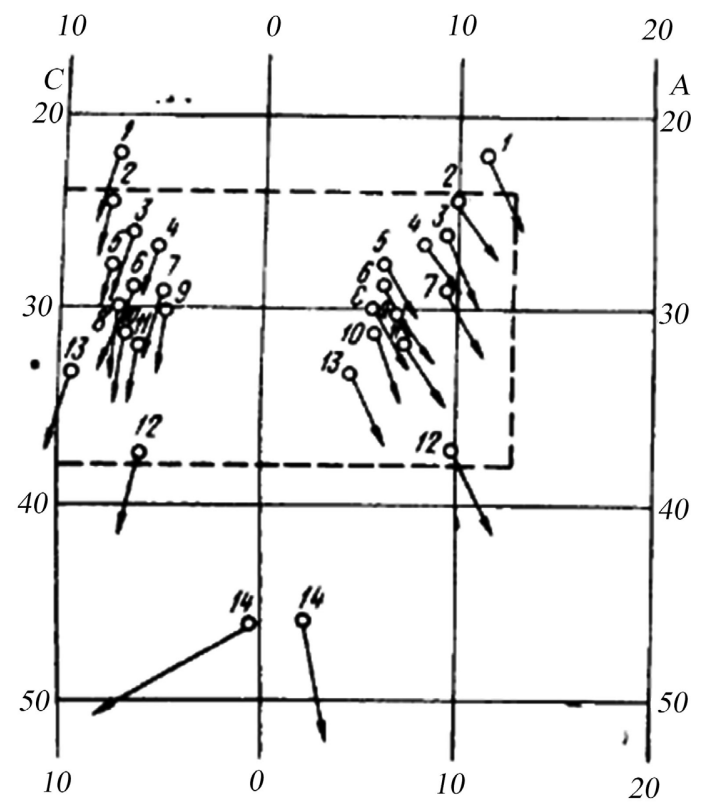

Figure 1. Zavaritsky's vector diagram (represented from reference [3]).

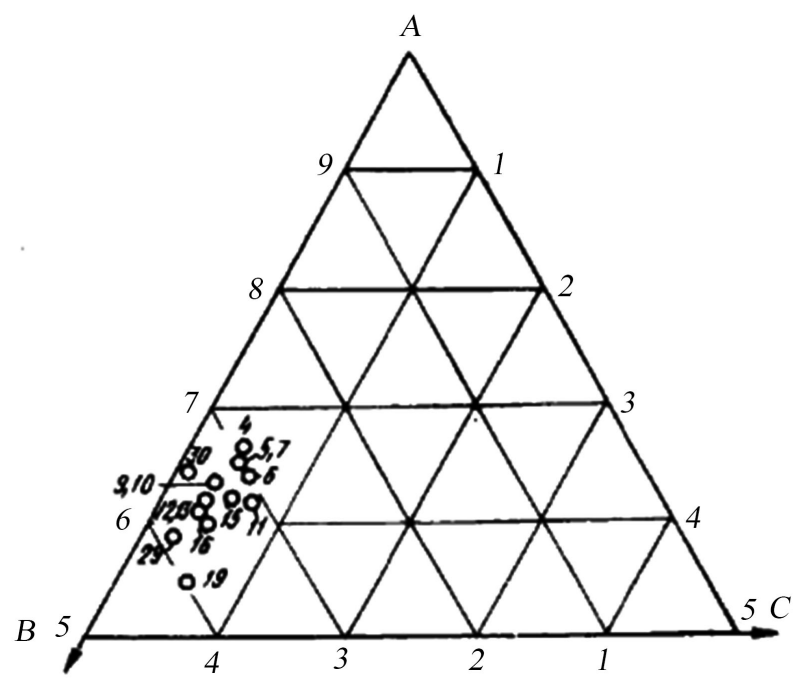

Figure 2. Ginsberg's projection diagram (represented from reference [3]). 


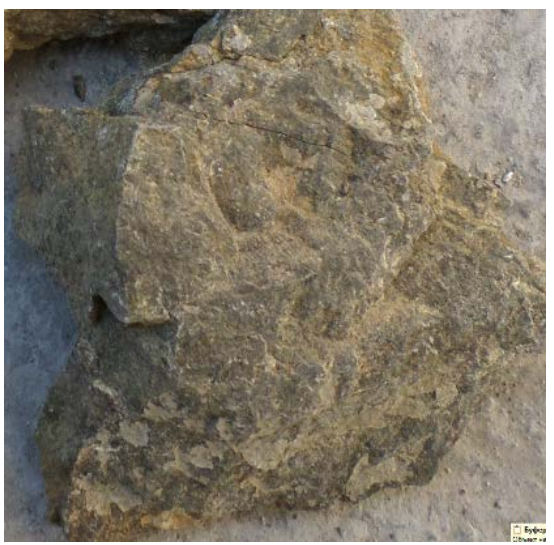

Figure 3. Basalt porphyry structure (image resolution $8 \times 8 \mathrm{~cm}$ ).

Most suitable for production of stone casting rocks with a coefficient in the range of $1.5-1.8$; at $\mathrm{K}>1.8-1.9$ and $\mathrm{K}<1.3$, charging is carried out with more basic and more acidic materials, respectively. This method does not give an answer which is from basic oxides should be add ( $\mathrm{CaO}, \mathrm{MgO}$ or $\mathrm{FeO})$.

Based on the additive law $y=c_{1} X_{1}+c_{2} X_{2}+\ldots$, a calculation formula proposed for determining the melting point of the basalt charge in the following form:

$$
\begin{aligned}
\Delta T_{\text {melt. }}= & V_{\mathrm{SiO}_{2}} \cdot T_{\text {melt. } \mathrm{SiO}_{2}}+V_{\mathrm{Al}_{2} \mathrm{O}_{3}} \cdot T_{\text {melt. } \mathrm{Al}_{2} \mathrm{O}_{3}}+V_{\mathrm{TiO}_{2}} \cdot T_{\text {melt. } \mathrm{TiO}_{2}} \\
& +V_{\mathrm{Fe}_{2} \mathrm{O}_{3}} \cdot T_{\text {melt. Fe }} \mathrm{O}_{3}+V_{\mathrm{FeO}} \cdot T_{\text {melt. FeO }}+V_{\mathrm{MgO}_{2}} \cdot T_{\text {melt. } \mathrm{MgO}} \\
& -V_{\mathrm{CaO}} \cdot T_{\text {melt. } \mathrm{CaO}}-V_{\mathrm{K}_{2} \mathrm{O}+\mathrm{Na}_{2} \mathrm{O}} \cdot T_{\text {melt. } \mathrm{K}_{2} \mathrm{O}+\mathrm{Na}_{2} \mathrm{O}} \pm\left(\mathrm{P}_{2} \mathrm{O}_{3}+\mathrm{MnO}+\mathrm{LI}\right) \%
\end{aligned}
$$

here in $\Delta T=T_{2}-T_{1}, T_{1}$ is initial temperature of basalt (ambient temperature); $T_{2}$ is basalt melt temperature (temperature in melting furnace); $V$ is the volumetric content of the specified element in basalt; $T_{\text {melt }}$ is the melting point corresponding to each $\mathrm{M}$ element constituting basalt; LOI means loss on ignition in percent (volatile elements, gases, hygroscopic water compounds). The resulting formula (3) proposed to determine the melting point of the basalt charge by calculation.

\section{Results and Discussions}

In this work, an aluminosilicate crystalline alloy was utilized in stone casting, which mainly consists of oxides: silicon oxide $\mathrm{SiO}_{2}$, aluminum oxide $\mathrm{Al}_{2} \mathrm{O}_{3}$, calcium oxide $\mathrm{CaO}$, magnesium oxide $\mathrm{MgO}$, iron oxides $\left(\mathrm{FeO}, \mathrm{Fe}_{2} \mathrm{O}_{3}\right)$, potassium oxide $\mathrm{K}_{2} \mathrm{O}$ and sodium oxide $\mathrm{Na}_{2} \mathrm{O}$. There are other oxides in the raw material, which we usually not consider in calculations; it has been established that the main structural element is a silicon-oxygen tetrahedron $\left(\mathrm{SiO}_{4}\right)^{-4}$ with a double bond, ionic and covalent. When silicon oxide $\mathrm{SiO}_{2}$ interacts with other oxides, it takes oxygen from them and forms various anionic radicals $\left[\mathrm{Si}_{2} \mathrm{O}_{7}\right]^{6-},\left[\mathrm{Si}_{3} \mathrm{O}_{9}\right]^{6-}$, $\left[\mathrm{Si}_{4} \mathrm{O}_{12}\right]^{9-}$, $\left[\mathrm{SiO}_{4}\right]^{4-}$, etc. Interaction of silicon-oxygen tetrahedral with cations modifiers is the main mineral-forming phase. Joining through oxygen, the silicon-oxygen tetrahedron $\left(\mathrm{SiO}_{4}\right)^{-4}$ forms various monosilicates or orthosilicates (Table 1). 
Table 1. Structural components in stone casting.

\begin{tabular}{l} 
No. Name \\
2 A group of three tetrahedrons connected in a ring inglated tetrahedron $\left[\mathrm{SiO}_{4}\right]^{4-}$ \\
\hline A group of six tetrahedrons linked in a ring $\left[\mathrm{Si}_{6} \mathrm{O}_{18}\right]^{12-}$
\end{tabular}

According to the classification by F. Zachariazen, silicate systems cations are divided into three groups: 1) Glass-forming with $\mathrm{Si}^{4+}$ with a strong covalent bond; 2) Network-destroying cations modifiers $\mathrm{Mg}^{2+}, \mathrm{Ca}^{2+}, \mathrm{Na}^{+}, \mathrm{K}^{+}, \mathrm{Fe}^{2+}, \mathrm{Fe}^{3+}$ that can replace $\mathrm{Si}^{4+}$ in complex with silicon-oxygen anions; 3) Intermediate group $\mathrm{Al}^{3-}$, $\mathrm{Ti}^{4+}$.

From a molecular point of view, a melt is a complex of different molecules connected by chemical bonds. The ionic theory considers a melt as a liquid filled with various simple cations and anions and various silicon-oxygen complexes consisting of $\left[\mathrm{Si}_{\mathrm{x}} \mathrm{O}_{\mathrm{y}}\right]^{\mathrm{z}}$ type.

A solid can be considered as a large molecule with positively and negatively charged ions interacting with each other, they create an equilibrium structure, being located in a certain way in the crystal lattice. The mutual arrangement of atoms in the crystal lattice affects the melting point. In the process of melting, complex physical and chemical processes occur; an increase in temperature intensifies these processes. The most famous deposit in the Kyrgyz Republic is Suluu-Terek, which is one of more than two hundred discovered. Basalt in Suluu-Terek deposit is one-component for obtaining basalt super thin fiber (BSTF). On spinnerets, the fiber is obtained long with a density from 15 to $25 \mathrm{~kg} / \mathrm{m}^{3}$ and an elementary fiber diameter from 3 to 8 microns. The filter-free technology of BSTF production with melt production in a gas furnace makes it possible to obtain a fiber with a shorter length, density from 40 to $90 \mathrm{~kg} / \mathrm{m}^{3}$ and an elementary 
fiber diameter from 1 to 3 microns. The fiber that is obtained by the electric melting method is obtained with an even shorter density from 50 to $120 \mathrm{~kg} / \mathrm{m}^{3}$ and from 1 to 3 microns [16] [17] [18].

\section{Basalt Characteristics}

Basalts undergo a change in aging over time. During this process, the main plagioclase (minerals of the albite series $\mathrm{NaAlSi}_{3} \mathrm{O}_{8}$ - anorthite $\mathrm{CaAl}_{2} \mathrm{Si}_{2} \mathrm{O}_{8}$ ) replaced by a saussurite aggregate (epidote + albite, chlorite, etc.) or pure albite and epidote. Colored silicates are replaced by: olivine - serpentine, talc, iddingsite; clinopyroxene - actinolite, chlorite; rhombic pyroxene - serpentine, chlorite. The glass is replaced by chlorite and minerals of the epidote group. As a result of such changes, metabasalts consist of albite, minerals of the epidote group, chlorite, actinolite, and leucoxene. The rocks acquire a greenish color, while the porphyry texture is usually retained (Figure 3 ).

O.Sh. Shamshiev notes about geological characteristics of the Suluu-Terek field [19] that basalt horizon is conventionally subdivided into three subhorizons: the lower subhorizon contain basalts with cryptocrystalline texture, i.e. (the mineral grains are so small that they are hardly distinguishable under a microscope). The cryptocrystalline structure of basalt from the Suluu-Terek deposit is shown in Figure 4.

Middle lawyer basalts characterized with amygdala, voids filled with calcite and secondary minerals, opal, chalcedony, quartz, carbonates, chlorite, etc. (Figure $5)$.

Upper layer contains basalts with carbonate veins. The percentage of sub horizons to the total area of basalt distribution (in the northern wing of the syncline) is as follows: cryptocrystalline basalts make up $40 \%$, amygdaloidal (formed when the voids are filled with secondary minerals), and is $50 \%$, basalts with carbonate veins $10 \%$ (Figure 6) [3].

Comparative analysis of the possibility of obtaining stone casting from basalts Suluu-Terek 1, Suluu-Terek 2, relatively not requiring charging, French, German, Czech are given in Table 2.

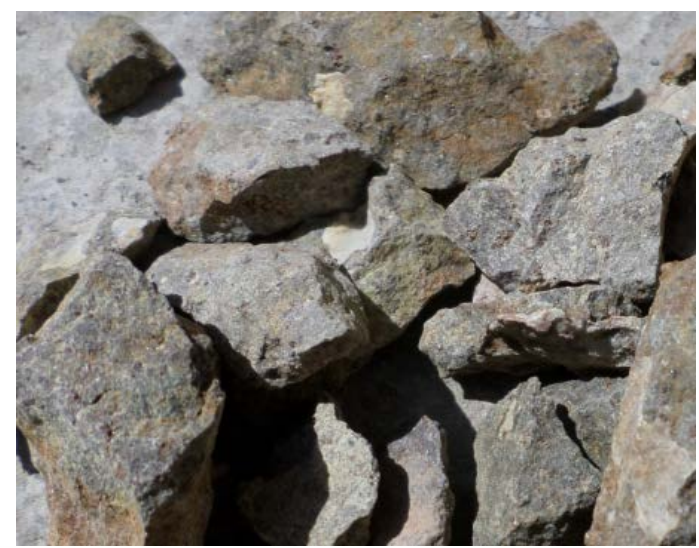

Figure 4. Cryptocrystalline structure basalt from $\mathrm{Su}-$ luu-Terek deposit (image resolution $8 \times 8 \mathrm{~cm}$ ). 
Table 2. Comparative chemical compositions of basalts from different places.

\begin{tabular}{cccccccccccc}
\hline \multirow{2}{*}{ Field } & \multicolumn{10}{c}{ Basalts chemical composition \% } \\
\cline { 2 - 11 } & $\mathrm{SiO}_{2}$ & $\mathrm{TiO}_{2}$ & $\mathrm{Al}_{2} \mathrm{O}_{3}$ & $\mathrm{Fe}_{2} \mathrm{O}_{3}$ & $\mathrm{FeO}$ & $\mathrm{MgO}$ & $\mathrm{CaO}$ & $\mathrm{Na}_{2} \mathrm{O}$ & $\mathrm{K}_{2} \mathrm{O}$ & Other & Losses in ignition \\
\hline French & 42.0 & - & 16.0 & 6.4 & 7.75 & 10.2 & 11.0 & 3.47 & 1.56 & 0.58 & 0.96 \\
German & 44.7 & 1.0 & 11.9 & 8.24 & 7.32 & 8.47 & 10.5 & 3.62 & 2.54 & 0.4 & 1.84 \\
Czeck & 42.3 & 2.52 & 16.3 & 8.43 & 5.46 & 5.49 & 9.7 & 4.45 & 1.92 & 1.09 & 2.43 \\
Ukrainian & 49.5 & 2.56 & 13.3 & 3.29 & 1.7 & 6.41 & 9.8 & 2.44 & 0.38 & 0.86 & 0.64 \\
Suluu-Terek 1 & 44.0 & 2.3 & 14.8 & 5.62 & 5.33 & 6.33 & 8.33 & 4.1 & 0.74 & 1.64 & 6.79 \\
Suluu-Terek 2 & 49.4 & 2.06 & 16.4 & 4.45 & 3.89 & 4.6 & 9.72 & 3.49 & 2.03 & 0.66 & 3.55 \\
\hline
\end{tabular}

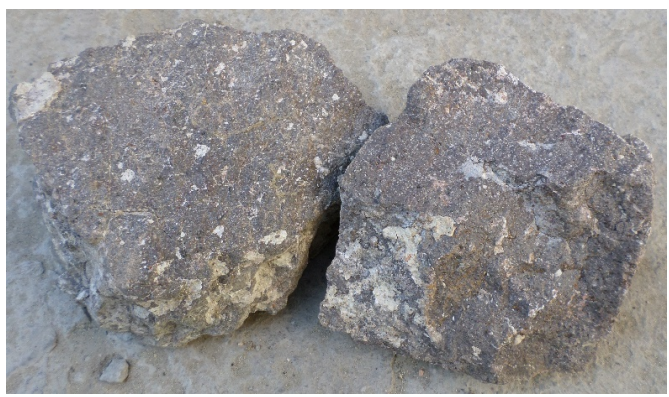

Figure 5. Basalt with tonsils (image resolution $8 \times 8$ $\mathrm{cm})$.

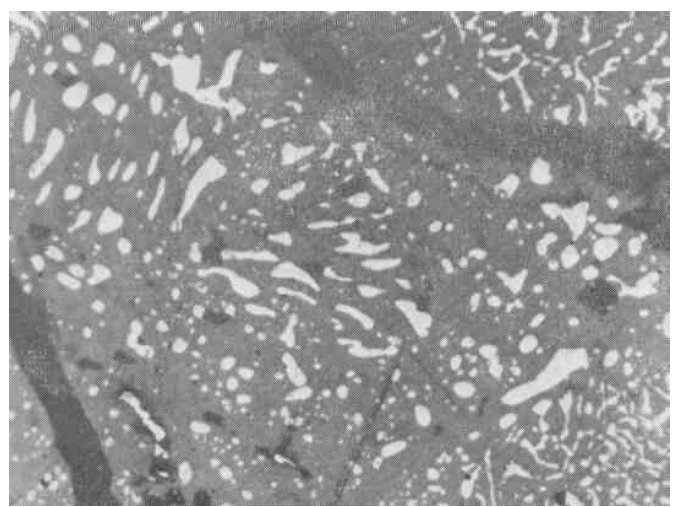

Figure 6. Basalt with carbonate stripes (image resolution $8 \times 8 \mathrm{~cm})$.

Suluu-Terek 1 (cryptocrystalline structure of basalt from the Suluu-Terek 1 and Suluu-Terek 2 deposits, basalt with carbonate veins) is a conventional name depending on $\mathrm{SiO}_{2}$ content in basalt rocks. According to chemical composition in Table 1, a comparative calculation carried out for molecular amount and acidity ratio, the results obtained after computational method summarized in Table 3.

Analysis in Table 3 shows that modulus of acidity K for the Suluu-Terek 1, Suluu-Terek 2 basalts overestimated and it is not necessary to mix these basalts with basic oxides. To determine the batch composition, three basalt deposits that do not require charging selected such as French, German and Czech. Following postulates obtained from the method by A.G. Boiler: 
Table 3. Chemical composition (\%), molecular amount (MA) and acidity coefficient (K) of various basalt deposits.

\begin{tabular}{|c|c|c|c|c|c|c|c|c|c|c|c|c|c|c|c|}
\hline \multirow{2}{*}{ Oxides } & \multicolumn{2}{|c|}{ French } & \multicolumn{4}{|c|}{ German } & \multicolumn{2}{|c|}{ Czech } & \multicolumn{4}{|c|}{ Suluu-Terek 1} & \multicolumn{3}{|c|}{ Suluu-Terek 2} \\
\hline & $\%$ & MA & K & $\%$ & MA & K & $\%$ & MA & K & $\%$ & MA & $\mathrm{K}$ & $\%$ & MA & $\mathrm{K}$ \\
\hline $\mathrm{SiO}_{2}$ & $\%$ & 0.7 & & 44.7 & 0.744 & & 42.3 & 0.704 & & 44.0 & 0.732 & & 49.4 & 0.822 & \\
\hline $\mathrm{TiO}_{2}$ & 42.0 & - & & 1.0 & 0.013 & & 2.52 & 0.032 & & 2.3 & 0.029 & & 2.1 & 0.026 & \\
\hline $\mathrm{Al}_{2} \mathrm{O}_{3}$ & - & 0.157 & & 11.9 & 0.117 & & 16.3 & 0.16 & & 14.8 & 0.145 & & 16.4 & 0.162 & \\
\hline $\mathrm{Fe}_{2} \mathrm{O}_{3}$ & 16 & 0.04 & & 8.24 & 0.052 & & 8.43 & 0.053 & & 5.62 & 0.035 & & 4.45 & 0.028 & \\
\hline $\mathrm{FeO}$ & 6.4 & 0.108 & 1.44 & 7.32 & 0.102 & 1.32 & 5.46 & 0.076 & 1.82 & 5.33 & 0.074 & 2.0 & 3.89 & 0.054 & 2.4 \\
\hline $\mathrm{MgO}$ & 7.75 & 0.253 & & 8.47 & 0.21 & & 5.49 & 0.136 & & 6.33 & 0.157 & & 4.6 & 0.114 & \\
\hline $\mathrm{CaO}$ & 10.2 & 0.194 & & 10.5 & 0.185 & & 9.7 & 0.171 & & 8.33 & 0.147 & & 9.72 & 0.171 & \\
\hline $\mathrm{Na}_{2} \mathrm{O}$ & 11.0 & 0.056 & & 3.62 & 0.058 & & 4.45 & 0.072 & & 4.1 & 0.066 & & 3.49 & 0.056 & \\
\hline $\mathrm{K}_{2} \mathrm{O}$ & 3.47 & 0.014 & & 2.54 & 0.027 & & 1.92 & 0.02 & & 0.74 & 0.008 & & 2.03 & 0.024 & \\
\hline
\end{tabular}

1) In petrochemical calculations, it is necessary to use molecular amounts of a substance;

2) Create pyroxene casting should be created by saturation of silicon oxide $\mathrm{SiO}_{2}$ with alkali, sesqui and basic oxides;

3) $\mathrm{SiO}_{4}$ tetrahedron in the crystalline structure of silicates interconnected in endless chains.

The comparison method was based on the following ways: we compared any of basalts that do not require charging (French, German and Czech), then calculate molar mass of $\mathrm{SiO}_{2}$ and the molecular weights of main oxides $\mathrm{FeO}, \mathrm{CaO}$, $\mathrm{MgO}$ and compare following: molecular amount $(\mathrm{MA}) \mathrm{SiO}_{2}$ (F) is 0.7; molecular amount (MA) $\mathrm{FeO}(\mathrm{F})$ is 0.108 ; molecular amount (MA) $\mathrm{SiO}_{2}(\mathrm{C} 1)$ is 0.732 ; required molecular amount (RMA) $\mathrm{X}: \mathrm{X}=0.7320 .108 / 0.7=0.113$.

For charging, it is necessary to additionally use $(0.113-0.074)=0.039$, MA $\mathrm{FeO}$ or $2.8 \%$ in percentage. To do this, it will be necessary to use padding materials presented in Table 4 . The rest of oxides calculated in a similar way, considering account in the basic oxides saturate $\mathrm{SiO}_{2}$. When using the German and Czech basalts for comparison, the calculated data may be different.

$\mathrm{FeO}$ lowers the viscosity and melting point of charge and lowers acidity of the melt. $\mathrm{CaO}$, when fused with $\mathrm{SiO}_{2}$, forms silicates. In melts, the viscosity decreases and it becomes "shorter". MgO Magnesium oxide affects the melt in a similar way to calcium oxide, but its effect is much greater. Calculation of MC additives to Suluu-Terek basalt given in Table 5 .

When using Suluu-Terek-1 basalt to obtain a pyroxene composition, it is necessary to add $10.3 \%$ of basic oxides, 2.8 of which is FeO. According to Table 4 we consider $14 \%$ to $15 \%$ of marble $(\mathrm{MgO}+\mathrm{CaO})=52.11 \%$ or $9 \%$ to $10 \%$ of dolomite. Calculation of charge amount including account of additives:

$$
Q=Q_{1} \times M_{1}+Q_{2} \times M_{2} / M_{1}+M_{2}
$$

here, $Q$ is calculated concentration of mixture; $Q_{1}$ is concentration of first component in \%; $Q_{2}$ is concentration of second component in \%; $M_{1}$ is mass or volume of first substance $(\mathrm{kg}, \mathrm{L}) ; M_{2}$ is the mass or volume of the second substance 
(kg, L). Charging results according to the chemical composition of raw materials (basalt, marble, chromium iron ore) according to the formula (5) are given in Table 6.

Table 4. Chemical composition of charging material.

\begin{tabular}{|c|c|c|c|c|c|c|c|}
\hline Species & $\mathrm{SiO}_{2}$ & $\mathrm{Al}_{2} \mathrm{O}_{3}$ & $\mathrm{CaO}$ & $\mathrm{MgO}$ & $\mathrm{FeO}$ & $\mathrm{Fe}_{2} \mathrm{O}_{3}$ & $\mathrm{Cr}_{2} \mathrm{O}_{3}$ \\
\hline & \multicolumn{7}{|c|}{$\%$} \\
\hline Dolomite & 11.0 & 2.5 & 50 & 28.0 & - & 3.0 & \\
\hline Hematite ore & 18.0 & 8.5 & - & 1.0 & - & 78.0 & \\
\hline Chromium iron ore & 6.5 & 15.5 & 1.5 & 15.5 & 15.5 & 8.0 & 36.5 \\
\hline Hornblendite & 37.75 & 15.0 & 11.2 & 12.4 & 14.5 & & \\
\hline Amphibolite & 44.22 & 16.83 & 12.2 & 7.81 & 14.13 & & \\
\hline Diabase & 50.42 & 13.35 & 8.0 & 3.99 & 15.92 & & \\
\hline Marble & - & - & 31.24 & 20.87 & - & - & \\
\hline
\end{tabular}

Table 5. Calculation of MA additives to basalt Suluu-Terek 1.

\begin{tabular}{|c|c|c|c|c|}
\hline \multirow[t]{2}{*}{ No. } & \multirow[t]{2}{*}{ Oxides } & \multirow{2}{*}{$\begin{array}{l}\text { Suluu-Terek-1 basalt } \\
\text { average composition (weight \%) }\end{array}$} & \multicolumn{2}{|c|}{ Recommended additives $\mathrm{FeO}, \mathrm{CaO}, \mathrm{MgO}$} \\
\hline & & & $\begin{array}{l}\text { Molecular quantities recommended } \\
\text { for addition to the charge }\end{array}$ & $\begin{array}{l}\text { Recommended weight } \\
\text { additions in\% for charge }\end{array}$ \\
\hline 1 & $\mathrm{SiO}_{2}$ & 44.0 & & \\
\hline 2 & $\mathrm{TiO}_{2}$ & 2.3 & & \\
\hline 3 & $\mathrm{Al}_{2} \mathrm{O}_{3}$ & 14.8 & & \\
\hline 4 & $\mathrm{Fe}_{2} \mathrm{O}_{3}$ & 5.62 & & \\
\hline 5 & $\mathrm{FeO}$ & 5.33 & $(0.113-0.074)=0.039$ & 2.8 \\
\hline 6 & $\mathrm{MgO}$ & 6.33 & $(0.265-0.157)=0.108$ & 4.35 \\
\hline 7 & $\mathrm{CaO}$ & 8.33 & $(0.203-0.147)=0.056$ & 3.17 \\
\hline 8 & $\mathrm{Na}_{2} \mathrm{O}$ & 4.1 & & \\
\hline 9 & $\mathrm{~K}_{2} \mathrm{O}$ & 0.74 & & \\
\hline \multirow[t]{2}{*}{10} & Other & 8.69 & & \\
\hline & Total & 100 & & \\
\hline
\end{tabular}

Table 6. Calculation of charge with addition of marble $(\mathrm{K}=1.54)$.

\begin{tabular}{|c|c|c|c|c|c|c|c|c|c|c|c|c|c|}
\hline \multirow{3}{*}{ Species name } & \multirow{3}{*}{$\%$} & \multicolumn{12}{|c|}{ Oxide composition } \\
\hline & & \multicolumn{2}{|c|}{$\mathrm{SiO}_{2}$} & \multicolumn{2}{|c|}{$\mathrm{Al}_{2} \mathrm{O}_{3}$} & \multicolumn{2}{|c|}{$\mathrm{CaO}$} & \multicolumn{2}{|c|}{$\mathrm{MgO}$} & \multicolumn{2}{|c|}{$\mathrm{FeO}$} & \multicolumn{2}{|c|}{$\mathrm{Fe}_{2} \mathrm{O}_{3}$} \\
\hline & & $\%$ & $\mathrm{Wt}$ & $\%$ & $\mathrm{Wt}$ & $\%$ & $\mathrm{Wt}$ & $\%$ & $\mathrm{Wt}$ & $\%$ & $\mathrm{Wt}$ & $\%$ & $\mathrm{Wt}$ \\
\hline Basalt & 14 & 44.0 & 83 & 14.8 & 83 & 8.33 & 83 & 6.33 & 83 & 5.33 & 83 & 5.62 & 83 \\
\hline Marble & & & & & & 31.24 & 19 & 20.87 & 19 & & & & \\
\hline Chromium iron ore & & 6.5 & 3 & 15.5 & 3 & 1.5 & 3 & 15.5 & 3 & 16.0 & 3 & 8.0 & 3 \\
\hline Calculated chemical composition & 3.0 & 41.02 & & 12.94 & & 11.66 & & 8.4 & & 5.7 & & 5.7 & \\
\hline
\end{tabular}


Addition of dolomite and iron chloride ore to charge calculated according to Table 7. Calculation of MA additives to basalt Suluu-Terek 2 for stone casting shown in Table 8.

The recommended addition is $8 \%-10 \%(\mathrm{MgO}+\mathrm{CaO})$ and $6 \%-7 \%$ iron oxide $\mathrm{FeO}$. Calculation of the charge with the addition of marble $(\mathrm{K}=1.52)$ is shown in Table 9.

Thus, basalts for stone casting with a cryptocrystalline structure from the lower horizon and amygdaloidal structures [20] from middle horizon require different amounts of charging materials, by both species and quantitative contents.

For comparison, we used the method to calculate addition of dolomite to the Berestovetsk basalt deposit at the Donetsk industrial complex of stone-cast and ceramic products (Table 10).

Table 7. Calculation of charge with addition of dolomite $(\mathrm{K}=1.6)$.

\begin{tabular}{|c|c|c|c|c|c|c|c|c|c|c|c|c|c|}
\hline \multirow{3}{*}{ Species name } & \multirow{3}{*}{$\%$} & \multicolumn{10}{|c|}{ Oxide composition } & & \\
\hline & & \multicolumn{2}{|c|}{$\mathrm{SiO}_{2}$} & \multicolumn{2}{|c|}{$\mathrm{Al}_{2} \mathrm{O}_{3}$} & \multicolumn{2}{|c|}{$\mathrm{CaO}$} & \multicolumn{2}{|c|}{$\mathrm{MgO}$} & \multicolumn{2}{|c|}{$\mathrm{FeO}$} & \multicolumn{2}{|c|}{$\mathrm{Fe}_{2} \mathrm{O}_{3}$} \\
\hline & & $\%$ & $\mathrm{Wt}$ & $\%$ & $\mathrm{Wt}$ & $\%$ & $\mathrm{Wt}$ & $\%$ & $\mathrm{Wt}$ & $\%$ & $\mathrm{Wt}$ & $\%$ & $\mathrm{Wt}$ \\
\hline Basalt & 88 & 44.0 & 88 & 14.8 & 88 & 8.33 & 88 & 6.33 & 88 & 5.33 & 83 & 5.62 & 88 \\
\hline Marble & 9 & 11.0 & & 2.5 & & 50.0 & 13 & 28.0 & 13 & & & 3.0 & \\
\hline Chromium iron ore & 3.0 & 6.5 & 3 & 15.5 & 3 & 1.5 & 3 & 15.5 & 3 & 16.0 & 3 & 8.0 & 3 \\
\hline $\begin{array}{l}\text { Calculated chemical } \\
\text { composition }\end{array}$ & 88 & 41.28 & & 13.76 & & 11.77 & & 8.12 & & 5.65 & & 5.35 & \\
\hline
\end{tabular}

Table 8. Calculation of MA additives to basalt Suluu-Terek-2 for stone casting.

\begin{tabular}{|c|c|c|c|c|}
\hline \multirow[t]{2}{*}{ No. } & \multirow[t]{2}{*}{ Oxides } & \multirow{2}{*}{$\begin{array}{l}\text { Suluu-Terek-2 basalt } \\
\text { average composition (weight \%) }\end{array}$} & \multicolumn{2}{|c|}{ Recommended additives $\mathrm{FeO}, \mathrm{CaO}, \mathrm{MgO}$} \\
\hline & & & $\begin{array}{l}\text { Molecular quantities recommended } \\
\text { for addition to the charge }\end{array}$ & $\begin{array}{l}\text { Recommended weight } \\
\text { additions in\% for charge }\end{array}$ \\
\hline 1 & $\mathrm{SiO}_{2}$ & 49.4 & & \\
\hline 2 & $\mathrm{TiO}_{2}$ & 2.06 & & \\
\hline 3 & $\mathrm{Al}_{2} \mathrm{O}_{3}$ & 16.4 & & \\
\hline 4 & $\mathrm{Fe}_{2} \mathrm{O}_{3}$ & 4.45 & & \\
\hline 5 & $\mathrm{FeO}$ & 3.89 & $(0.127-0.028)=0.099$ & 7.13 \\
\hline 6 & $\mathrm{MgO}$ & 4.6 & $(0.297-0.114)=0.183$ & 7.38 \\
\hline 7 & $\mathrm{CaO}$ & 9.72 & $(0.228-0.171)=0.057$ & 3.24 \\
\hline 8 & $\mathrm{Na}_{2} \mathrm{O}$ & 3.49 & $(0.127-0.028)=0.099$ & 7.13 \\
\hline 9 & $\mathrm{~K}_{2} \mathrm{O}$ & 2.03 & & \\
\hline \multirow[t]{2}{*}{10} & Other & 5.96 & & \\
\hline & Total & 100 & & \\
\hline
\end{tabular}


Finally, it is necessary to add $(1.36+1.65+1.93)=4.94 \%$ of the basic oxides. If we choose dolomite for the additive, where $\mathrm{CaO} 50 \%+\mathrm{MgO} 28 \%=78 \%$ i.e. it is necessary to use $6.3 \%$. At the Donetsk plant for stone-cast and ceramic products, $6 \%-8 \%$ of dolomite is added to basalt in the Berestovetsk deposit, and $3 \%$ of chromium iron ore was add over $100 \%$, i.e. calculations were confirmed. Table 11 shows calculated value of the melting temperature during charge depending on chemical composition and measured with a thermocouple.

Table 9. Calculation of charge with addition of marble $(\mathrm{K}=1.52)$.

\begin{tabular}{|c|c|c|c|c|c|c|c|c|c|c|c|c|c|}
\hline \multirow{3}{*}{ Species name } & \multirow{3}{*}{$\%$} & \multicolumn{12}{|c|}{ Oxide composition } \\
\hline & & \multicolumn{2}{|c|}{$\mathrm{SiO}_{2}$} & \multicolumn{2}{|c|}{$\mathrm{Al}_{2} \mathrm{O}_{3}$} & \multicolumn{2}{|c|}{$\mathrm{CaO}$} & \multicolumn{2}{|c|}{$\mathrm{MgO}$} & \multicolumn{2}{|c|}{$\mathrm{FeO}$} & \multicolumn{2}{|c|}{$\mathrm{Fe}_{2} \mathrm{O}_{3}$} \\
\hline & & $\%$ & $\mathrm{Wt}$ & $\%$ & $\mathrm{Wt}$ & $\%$ & $\mathrm{Wt}$ & $\%$ & $\mathrm{Wt}$ & $\%$ & $\mathrm{Wt}$ & $\%$ & $\mathrm{Wt}$ \\
\hline Basalt & 72 & 49.4 & 72 & 16.4 & 72 & 9.72 & 72 & 4.6 & 88 & 3.9 & 72 & 4.45 & 72 \\
\hline Marble & 18 & & & & & 31.3 & 19 & 209 & 13 & & & & \\
\hline Iron oxide (II) & 7 & & & & & & & & & 90 & & & \\
\hline Chromium iron ore & 3.0 & 6.5 & 3 & 15.5 & 3 & 1.5 & 3 & 15.5 & 3 & 16.0 & 3 & 8.0 & 3 \\
\hline $\begin{array}{l}\text { Calculated chemical } \\
\text { composition }\end{array}$ & & 47.68 & & 16.4 & & 14.0 & & 7.85 & & 11.5 & & 4.59 & \\
\hline
\end{tabular}

Table 10. Calculation of MA for the composition of basalt of the Berestovetsk deposit.

\begin{tabular}{|c|c|c|c|c|}
\hline \multirow[t]{2}{*}{ No. } & \multirow[t]{2}{*}{ Oxides } & \multirow{2}{*}{$\begin{array}{l}\text { Berestovetsk basalt } \\
\text { average composition (weight \%) }\end{array}$} & \multicolumn{2}{|c|}{ Recommended additives $\mathrm{FeO}, \mathrm{CaO}, \mathrm{MgO}$} \\
\hline & & & $\begin{array}{l}\text { Molecular quantities recommended } \\
\text { for addition to the charge }\end{array}$ & $\begin{array}{l}\text { Recommended weight } \\
\text { additions in } \% \text { for charge }\end{array}$ \\
\hline 1 & $\mathrm{SiO}_{2}$ & 49.46 & & \\
\hline 2 & $\mathrm{TiO}_{2}$ & 2.56 & & \\
\hline 3 & $\mathrm{Al}_{2} \mathrm{O}_{3}$ & 13.28 & & \\
\hline 4 & $\mathrm{Fe}_{2} \mathrm{O}_{3}$ & 3.29 & & \\
\hline 5 & $\mathrm{FeO}$ & 10.7 & $(0.127-0.108)=0.019$ & 1.36 \\
\hline 6 & $\mathrm{MgO}$ & 6.41 & $(0.294-0.253)=0.041$ & 1.65 \\
\hline 7 & $\mathrm{CaO}$ & 9.8 & $(0.228-0.194)=0.034$ & 1.93 \\
\hline 8 & $\mathrm{Na}_{2} \mathrm{O}$ & 2.44 & $(0.127-0.108)=0.019$ & 1.36 \\
\hline 9 & $\mathrm{~K}_{2} \mathrm{O}$ & 0.38 & & \\
\hline \multirow[t]{2}{*}{10} & Other & 1.68 & & \\
\hline & Total & 100 & & \\
\hline
\end{tabular}

Table 11. Melting temperature of basalt mixture.

\begin{tabular}{ccc}
\hline Names of basalt rocks & $\begin{array}{c}\text { Melting temperature of basalt rocks } \\
\text { according to the formula (3), }{ }^{\circ} \mathrm{C}\end{array}$ & $\begin{array}{c}\text { Melting temperature of basalt rocks } \\
\text { according to the formula (experiment), }{ }^{\circ} \mathrm{C}\end{array}$ \\
\hline Suluu-Terek 1 & $1147.56 \pm 4$ & 1180 \\
Suluu-Terek 2 & $1225.57 \pm 4$ & 1350 \\
\hline
\end{tabular}




\section{Conclusions}

After above work we made following conclusions:

1) Analysis of methods for evaluating raw materials in production technology of stone casting. A comparative method for evaluating raw materials for producing stone casting has been worked out;

2) The working chemical composition of the Suluu-Terek 1 and Suluu-Terek 2 basalts has been determined. The calculation of basalt raw materials with charging materials has been made. On the basis of the chemical composition according to the obtained formula, the melting points of the basalt charge were determined;

3) Essence for a method for calculating charging, by comparing the raw materials used in the production of stone casting was revealed. The results obtained are in complete agreement with the experimental data.

\section{Conflicts of Interest}

The authors declare no conflicts of interest regarding the publication of this paper.

\section{References}

[1] McCloy, J.S., Marcial, J., Clarke, J.S., Ahmadzadeh, M., Wolff, J.A., Vicenzi, E.P., Bollinger, D.L., Ogenhall, E., Englund, M., Pearce, C.I., Sjöblom, R. and Kruger, A.A. (2021) Reproduction of Melting Behavior for Vitrified Hillforts Based on Amphibolite, Granite, and Basalt Lithologies. Scientific Reports, 11, Article No. 1272. https://doi.org/10.1038/s41598-020-80485-w

[2] Andreev, V.V., Kayak, G.L., Chashchin, A.A., Karabtsov, A. A. and Chashchin, S. A. (2017) Investigation of the Technology of Obtaining Glass-Crystalline Materials Based on Basalts of the Primorsky Territory. Bulletin of the Engineering School of the Far Eastern Federal University, 3, 156-166.

[3] Lipovsky, I.E. and Dorofeev, V.A. (1972) The Basics of Petrurgy. Metallurgy, Moscow, p. 320.

[4] Gramenitskiy, E.N., Kotelnikov, A.R., Batanova, A.M., Shekina, T.I. and Plechov, P.Y. (2000) Experimental and Technical Petrology. Scientific World, Moscow, p. 416.

[5] Kotlova, A.G. (1958) Some Data on the Crystallization of Basaltic Pyroxene Melts and Glasses. USSR Academy of Sciences 1958, Issue 30.

[6] Leontyeva, A.A. (1950) Fused Basalts, Their Properties and Applications. Institute of Fossil Fuels of the USSR Academy of Sciences, Petrographic Series, No. 39.

[7] Nashelsky, A.M. and Lipovsky, I.E. (1966) Determination of the Casting Properties of the Stone Melt. Liteinoe Proizvodstvo, 8, 28-30.

[8] Yarygin, V.I. (1965) Some Questions of Petrography of the Chanysh Massive (Gorny Altai). Izvestia TPU, 135, 124-135.

[9] Lipovsky, I.E. and Dorofeev, V.A. (1960) Stone Casting for Industry. Metallurgy, 3, 14-20.

[10] Fomichev, S.V., Babievskaya, I.Z., Dergacheva, N.P., Noskova, O.A. and Krenev, V.A. (2010) Assessment and Modification of the Initial Composition of Gabbro-Basalt Rocks for the Production of Mineral Fibers and Stone Casting Products. 
Inorganic Materials, 46, 1240-1245. https://doi.org/10.1134/S0020168510100171

[11] Rashin, G.A. and Chetverikov, S.D. (1964) Petrochemical Method for Evaluating Raw Materials for Stone Casting. Universities News, Geology and Exploration, 9, 71-79.

[12] Chetverikov, S.D. (1956) A Guide to Petrochemical Recalculations of Chemical Analyzes of Rocks and the Determination of Their Chemical Types. Gosgeoltekhizdat, Moscow, 246 p.

[13] Yarygin, V.I. (1971) Main Features of Geology and Petrography of the Lebedsky Pluton (Mountainous Altai). Izvestiya TPU, 177, 118-126.

[14] Lebedeva, G.A., Ozerova, G.P. and Kalinin, Y.K. (1979) Classification of Petrurgical Raw Materials. Science, Leningrad, 120 p.

[15] Redkin, G.I., Krasyukova, E.I. and Ovcharova, N.V. (2018) Classification of Rocks Based on Their Structure. Vector GeoNauk, 1, 23-26.

[16] Ormonbekov, T.O. (1997) Basalt Fiber Technology and Products on Their Base. Technology, Bishkek, p. 122.

[17] Abdykalykov, A.A., Aidaraliev, Z.K. and Dubinin, Y.N. (2014) Equipment and Composition of the Charge for Producing Basalt-Stone Casting. Integration, Partnerships and Innovations in Building Science and Education: Collection of Scientific Papers of the International Scientific Conference, Moscow, 12-13 November 2015, 479-484.

[18] Aidaraliev, Z.K., Kainazarov, A.T., Ismanov, Y.K., Abdiev, M.S. and Atyrova, R.S. (2019) Mineralogical Phases Formed during the Crystallization of Molten Igneous Rocks. International Journal of Applied and Fundamental Research, 2, 7-11. https://doi.org/10.17513/mjpfi.12661

[19] Shamshiev, O.S., Chekushina, E.V. and Baltaeva, G.A. (2014) Geological Characteristics and Structure of the Suluu-Terekskoye Basalt Deposit (Kyrgyzstan). Bulletin of the Peoples' Friendship University of Russia, Series. Engineering Research, 2, 55-63.

[20] Ignatova, A.M. and Shekhireva, A.M. (2011) Comparative Petrography of Natural Materials and Synthetic Mineral Alloys of Stone Casting. Perm University Bulletin, Geology, 4, 20-31. 